\title{
Limnology of an integrated cage-pond aquaculture farm
}

\author{
Limnologia de um sistema integrado tanques-rede e viveiro em fazenda de aquicultura
}

\section{Lúcia Helena Sipaúba-Tavares $^{1 *}$, Rodrigo Ney Millan² and Ana Milstein ${ }^{3}$}

${ }^{1}$ Laboratório de Limnologia e Produção de Plâncton, Centro de Aquicultura, Universidade Estadual Paulista - UNESP, CEP 14884-900, Jaboticabal, SP, Brazil

${ }^{2}$ Departamento de Ciências Exatas e da Terra, Universidade do Estado de Minas Gerais - UEMG, CEP 38200-000, Frutal, MG, Brazil

${ }^{3}$ Agricultural Research Organization, Fish and Aquaculture Research Station Dor, M.P. Hof HaCarmel, 30820, Israel

*e-mail: sipauba@caunesp.unesp.br

Cite as: Sipaúba-Tavares, L.H., Millan, R.N. and Milstein, A. Limnology of an integrated cage-pond aquaculture farm. Acta Limnologica Brasiliensia, 2016, vol. 28, e1.

Abstract: Aim: Examining whether small-scale tilapia cages have a potential influence on water abiotic parameters in a pond of a flow-through system. Methods: Tilapia cages were installed near the pond water outlet. Samples for determination of abiotic parameters were monthly collected during eight months at five sampling sites: near three inlets receiving effluents from other fishponds (IW12, IW6 and IWM, the latter opening in a macrophyte bed), close to the cages in the open-pond (CC) and close to the water outlet (WO). The data were analyzed using Principal Component Analysis (PCA). Results: The first PCA axis (70\% of the data variability) was related to eutrophication and the second axis $(20 \%)$ to the dependence of nitrifying bacteria on substrate availability. The sampling sites IW12, CC and WO showed high eutrophication levels. The lowest total phosphorus content, total suspended solids, hardness, alkalinity and conductivity and the highest dissolved oxygen were observed in the macrophyte bed area (IWM). Fish cages significantly increased total phosphorus content, conductivity, alkalinity and hardness in relation to the macrophyte bed inlet. Water outlet abiotic parameters were similar to near cage water. Conclusion: The integrated cage-pond technology may be utilized in flow-through systems if incoming water quality (mainly in the site W12) is improved. Cages should be positioned closer to the pond center where it is deeper allowing higher flow-through and dispersion of uneaten feed residues and feces from the cages. This would avoid their deposition beneath cages and reduce their negatives influence on water quality entering the next fishpond (WO), and therefore not impair fish performance.

Keywords: cage culture; integrated culture; limnological parameters; Nile tilapia.

Resumo: Objetivo: Foram avaliados os parâmetros abióticos de um sistema integrado de piscicultura e tanques-rede com fluxo contínuo de água. Métodos: Os tanques-rede para criação de tilápias foram instalados próximos à saída de água. Amostras para determinação dos parâmetros abióticos foram coletadas mensalmente durante oito meses em cinco locais: três próximos às entradas de água que recebem efluentes de outros viveiros (IW12, IW6 e IWM, este último ponto situa-se dentro de um banco de macrófitas), um próximo aos tanques-rede (CC) e outro próximo à saída de água (WO). Os dados foram analisados a través de componentes principais (ACP). Resultados: $\mathrm{O}$ primeiro eixo da ACP ( $70 \%$ da variabilidade dos dados) está relacionado com a eutrofização e o segundo (20\%) com as bactérias nitrificantes. Os pontos IW12, CC e WO foram os mais eutróficos. O menor teor de fósforo total, sólidos totais suspensos, dureza, alcalinidade e condutividade e o maior teor de oxigênio dissolvido foram observados no ponto próximo às macrófitas. Os tanques-rede aumentaram significativamente o conteúdo de fósforo total, condutividade, alcalinidade e dureza 
da água em relação ao ponto de água que passa pelo banco de macrófitas. As variáveis limnológicas no ponto amostral próximo à saída de água foram semelhantes ao ponto próximo aos tanques-rede. Conclusáo: A tecnologia que integra tanque-rede e viveiro de piscicultura pode ser utilizada em sistema com fluxo contínuo desde que ocorra adequação na qualidade da água na entrada do viveiro (principalmente no local W12) e, posicionar os tanques-rede próximos ao centro do viveiro, onde é mais profundo permitindo maior fluxo de água e maior dispersão dos resíduos alimentares e fezes que podem se depositar abaixo das gaiolas e também, para não influenciar a qualidade da água que flui diretamente para o outro viveiro (WO) e, consequentemente, prejudicar o desempenho do peixe.

Palavras-chave: cultivo em tanque-rede; cultivo integrado; parâmetros limnológicos; tilápia do Nile.

\section{Introduction}

Cage farming of aquatic organisms is widespread around the world. As cage aquaculture becomes more prevalent, the problem of water pollution caused by the input of artificial feeds will certainly become more serious. In many cases, caged fish are fed with high protein diets; wastes derived from the feed are either directly or indirectly released to the surrounding environment, causing accelerated eutrophication in those waters (Yi \& Lin, 2001a).

In the last few decades increasing environmental pressure, land utilization and economic feasibility, among other factors, encouraged the search for alternatives to traditional aquaculture methods. One of such alternatives is the integrated cage-pond system, in which fish culture in cages is integrated with semi-intensive culture of other fish species in the open-pond. Fish in the cages are fed artificial diets while the fish in the open-pond utilize natural foods and wastes escaping the cages, so that the wastes of one species become nutritional inputs for another (Yi \& Lin, 2001a; Yadav et al., 2007). As a result, ponds do not require fertilization avoiding accelerated eutrophication of pond water produced by excessive nutrients (Yi \& Lin, 2001b), and the feed utilization is improved through nutrients recycling within the fishpond (Waidbacher et al., 2006). On the other hand, excess feeding may increase suspended solids and nutrients in the water column (Huo et al., 2012) and an excess of nutrients rich waste released into the cage surrounding environment may accumulate and lead to adverse conditions (Degefu et al., 2011; Vista et al., 2006; Yi \& Lin, 2001b). Knowledge of local conditions and appropriate management are essential to obtain and maintain proper water quality in cage-pond systems (Waidbacher et al., 2006).

In the past, building large fish ponds for fish culture was common in Brazil. Nowadays with the water scarcity and difficulties of fish management in this kind of ponds farmers consider the existing large ponds unsuitable for fish culture. The implementation of cages in this kind of fishponds would be a good alternative technology to efficiently use these systems without negatively affecting environmental conditions.

In the farm studied aquaculture is carried out in a flow-through system in which large earthen ponds are disposed in line, each pond receiving the effluents from the previous one. There is insufficient knowledge about water quality relationships between ponds and fish cages within them in flow-through systems. The present study aims at examining whether a small scale tilapia cage system has a potential influence the water abiotic parameters when integrated into a pond of a flow-through fishponds system, and to provide useful limnologic information for further aquaculture planning in these systems.

\section{Methods}

\subsection{Study area}

The study was carried out during eight months in a fishpond of the Aquaculture Center (210 $15^{\prime} \mathrm{S}$ and $48^{\circ} 17^{\prime} \mathrm{W}$ ) of the University of São Paulo State (UNESP) at Jaboticabal (SP, Brazil) (Figure 1). The fishpond is $1822 \mathrm{~m}^{2}$ in area, $1.1 \mathrm{~m}$ deep, and has a continuous water flow with a daily exchange rate of $5 \%$ of its volume (exchange rate calculated as $\left.1.15 \mathrm{~L} . \mathrm{s}^{-1}\right)$. This fishpond is the second of 6 similar size fishponds in a sequential line each directly or indirectly receiving water from the previous one (Figure 1). The studied fishpond has three water inlets. The inlet pipe in the northern end receives water from an ornamental fish laboratory and four $200 \mathrm{~m}^{2}$ fishponds, and opens in a macrophyte bed. The inlet pipe in the northwestern side receives water from twelve $45 \mathrm{~m}^{2}$ fishponds. The inlet pipe in the northeast side receives water from six $80 \mathrm{~m}^{2}$ fishponds. All fishponds source of water for the studied pond receive water from the first pond in the line, and had an average fish density of 1 fish. $\mathrm{m}^{2}$. The water outlet is located in the southern end of the pond (Figure 1). 


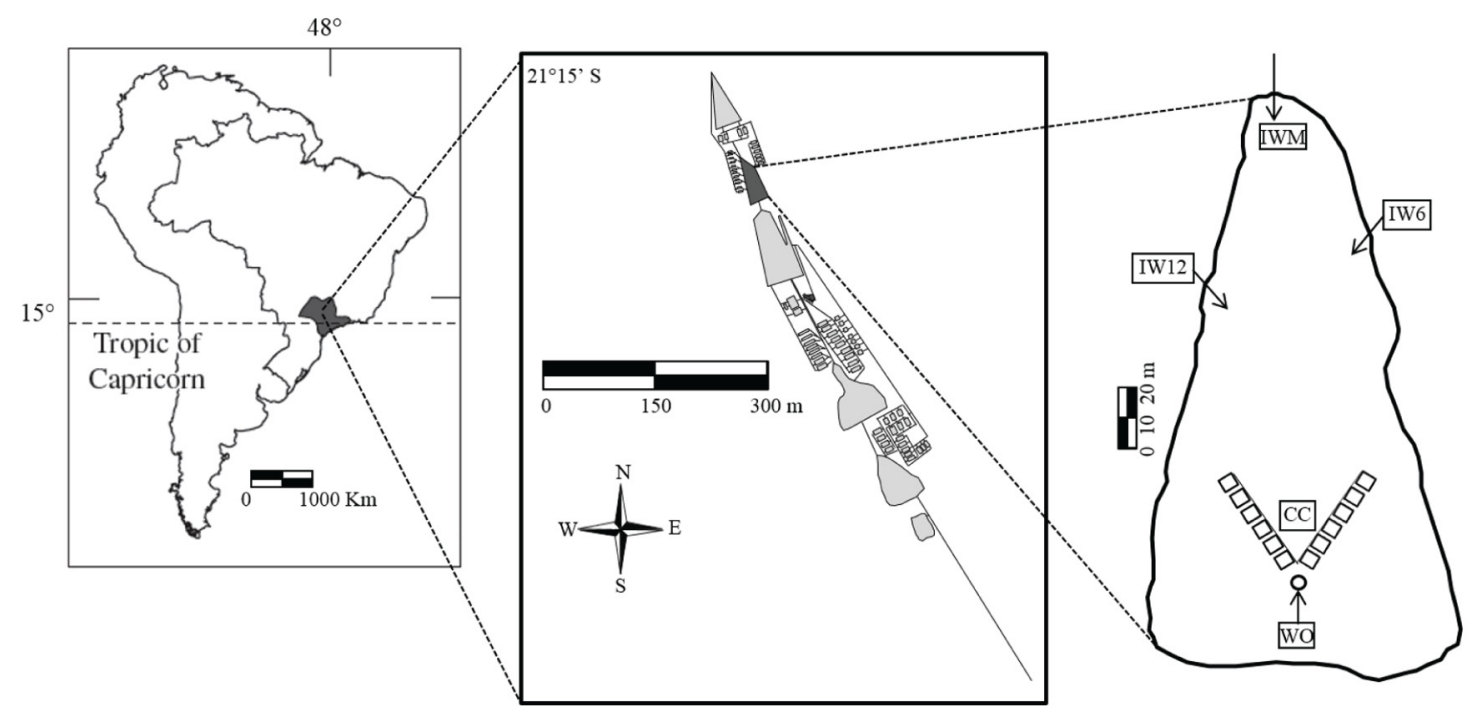

Figure 1. Location of the fishpond studied. $\mathrm{CC}=$ close to cages in the open-pond; $\mathrm{WO}=$ water outlet; $\mathrm{IW} 12=$ water inlet receiving effluents from 12 fishponds; IW $6=$ water inlet receiving effluents from 6 fishponds; IWM= water inlet opening into a macrophyte bed.

\subsection{Fish management}

In the southern side of the fishpond, 12 metal frame cages $(2 \times 2 \times 1.1 \mathrm{~m}$ each $)$ covered with $2 \mathrm{~cm}$ mesh nylon nets were suspended $20-\mathrm{cm}$ over the pond bottom, maintaining $0.90 \mathrm{~m}$ water depth in the cages. In each cage, small Nile tilapias (about $20 \mathrm{~g}$ ) were stocked by the end of October at a density of 80 fish. $\mathrm{m}^{3}$, and were cultured during 8 months (October to May 2008). Three times a day tilapias in the cages were fed floating pelleted feed with $30 \%$ crude protein, at a rate of $3 \%$ weight/day. Salt was added in the cages three times a day during the first three weeks to treat Monogenea ectoparasites. From the third week on aeration close to the cages was applied for $10 \mathrm{~h}$ during the nights. Free, in the open pond remained the 1 fish. $\mathrm{m}^{3}$ population of the fish "pacu" (Piaractus mesopotamicus) and "tambaqui" (Colossoma macropomum) that already existed in this fishpond, whose individual weight by the start of this study was about $500 \mathrm{~g}$. These fish were not fed and obtained their nutrition from wastes escaping cages and materials entering in the inlet waters. The fishpond was not fertilized.

\subsection{Samples sites and limnologic variables}

Water samples were monthly collected within the fishpond at five sampling sites: $\mathrm{CC}=$ close to cages in the open pond, $\mathrm{WO}=$ close to the water outlet, IW12 = close to the western inlet pipe receiving water from 12 fishponds, IW6 = close to the eastern inlet pipe receiving water from six fishponds, IWM = close to the northern inlet pipe inside the macrophyte bed receiving water from an ornamental fish laboratory and four fishponds (Figure 1).

Physical and chemical variables were sampled at 8:00 AM from $10 \mathrm{~cm}$ depth. Samples were collected with a $1 \mathrm{~L}$ Van Dorn bottle and transported in refrigerated polyethylene bottles to laboratory. Temperature (Temp), $\mathrm{pH}$, dissolved oxygen (DO) and conductivity (Cond) were measured in situ using a multi-sensor Horiba U-10. Total phosphorus (TP), orthophosphate (OP), total ammonia nitrogen (TAN), nitrite (NO2) and nitrate (NO3), were quantified spectrophotometrically according to Golterman et al. (1978) and Koroleff (1976). Chlorophyll-a (Chl-a) was extracted with 90\% alcohol and quantified at $663 \mathrm{~nm}$ and $750 \mathrm{~nm}$ (Nusch, 1980). Hardness (Hd), 5-day biochemical oxygen demand (BOD), total suspended solids (TSS) and total dissolved solids (TDS) were determined according to Boyd \& Tucker (1992), and alkalinity (Alk) according to Mackereth et al. (1978). Analyses were performed immediately after sampling or samples were duly stored under refrigeration.

At the beginning and end of the experiment, mean fish weight was computed in each cage. Fish parameters measured or calculated were: initial weight (IW, g.fish ${ }^{-1}$ ), final weight (FW, g.fish ${ }^{-1}$ ), weight gain (WG $=\mathrm{FW}-\mathrm{IW}$ ), and specific growth rate $(S G R=100[\ln (F W)-\ln (\mathrm{IW}) /$ culture period in days $\left.{ }^{-1}\right]$. Routine growth monitoring of pond fish was not performed. 


\subsection{Statistical analysis}

Principal Components Analysis (PCA) was used to reduce the dimensionality of the environmental variables and to rank the sites in relation to the characteristics of water samples collected in the fishpond (Legendre \& Legendre, 1998). PCA was run on the average values measured in each sampled point $(n=5)$. Statistical analyses were performed with Statistica 8.0 (StatSoft Inc., 2007).

\section{Results}

Table 1 summarizes water quality data by sampling site. Inlet water in the macrophyte bed (IWM) showed low TP contents, hardness, BOD, conductivity and alkalinity and high DO in relation the other inlet water sources. Total phosphorus and hardness were respectively about $60 \%$ and $20 \%$ lower in the IWM than the other two inlet sources (IW12 and IW6). Alkalinity and conductivity were about 20\% lower in the IWM than in the IW12 inlet, while in the IW6 inlet they were intermediate (Table 1). Close to cages in the open pond higher values of TP, conductivity and alkalinity in relation to the macrophyte bed inlet were observed. These differences were not observed in relation to the other water inlets. In general the total ammonia nitrogen (TAN) and orthophosphate (OP) decreased from February to May in the CC site and DO increased in all sites. Nitrate was high during the experimental period. Temperature was directly affected by local climatic conditions (Figure 2). All parameters were similar in the water outlet (WO) near the cages (CC) and close to the western inlet pipe (IW12) (Table 1; Figure 2).

Table 2 and Figure 3 present the results of the principal component analysis (PCA) of water variables. The first axis (PC1), accounting for $70 \%$ of the data variability, is bipolar with three variables in its positive side (DO, NO2 and NO3) and almost all the remaining water variables in its negative side. It reflects eutrophication: in more eutrophic waters (low PC1 values) prevail high chlorophyll-a and decomposition that liberates ammonia and phosphorus (high TAN, OP and TP) into the water column consuming oxygen (high BOD and low DO) that prevents nitrification (high TAN and low nitrite and nitrate). The sampling sites WO, CC and IW12 were associated to the negative coefficient variables showing high eutrophication, while water entering in the macrophyte bed (IWM) was associated to the positive ones showing clearer waters. The second axis (PC2), accounting for a further $20 \%$ of the data variability, groups TSS, $\mathrm{NO}_{3}$ and $\mathrm{NO}_{2}$ with negative coefficients. It reflects another aspect of nitrification: dependence of nitrifying bacteria on substrate availability, so that the more TSS the more nitrification. Inlet water from IW6 was associated to this axis (Figure 3).

The fish grown in the cages did not reach marketable size $(700 \mathrm{~g})$ by the end of the experimental period (243 days). Tilapia performance in the cages was poor, with $230 \mathrm{~g}$ final mean weight, 210 g weight gain, 0.8 g.day ${ }^{-1}$ growth rate and $1.8 \%$ day $^{-1}$ SGR. From the twelve cages were obtained $750 \mathrm{Kg}$ tilapia, equivalent to a harvested biomass of $15.6 \mathrm{Kg} \cdot \mathrm{m}^{-3}$. The parasitosis detected after stocking resulted in $15 \%$ mortality.

\section{Discussion}

The reduced amount of nutrients and solids entering with the source water together with the 'cleaning' capability by the macrophytes resulted in (a) a lower eutrophic level than in the other inlets, as identified by the first principal component (IWM

Table 1. Mean and standard deviation of water variables collected in five sites during the studied period.

\begin{tabular}{lccccc}
\hline \multirow{2}{*}{\multicolumn{1}{c}{ Limnologic Parameters }} & \multicolumn{5}{c}{ SITES } \\
\cline { 2 - 6 } & CC & WO & IW12 & IW6 & IWM \\
\hline Nitrite $(\mu \mathrm{g} / \mathrm{L})$ & $9.8 \pm 9.4$ & $9.2 \pm 8.1$ & $10.4 \pm 12.1$ & $16.7 \pm 31.5$ & $14.6 \pm 33.6$ \\
Total Phosphorus $(\mu \mathrm{g} / \mathrm{L})$ & $50.2 \pm 22.1$ & $68.8 \pm 52.4$ & $64.4 \pm 35.8$ & $46.5 \pm 15.7$ & $26.7 \pm 7.3$ \\
Conductivity $(\mu \mathrm{S} / \mathrm{cm})$ & $74.3 \pm 9.0$ & $73.9 \pm 9.7$ & $74.9 \pm 11.1$ & $64.6 \pm 9.2$ & $56.9 \pm 7.9$ \\
Total Dissolved Solids $(\mathrm{mg} / \mathrm{L})$ & $40.6 \pm 15.5$ & $88.6 \pm 86.7$ & $49.6 \pm 15.8$ & $55.4 \pm 19.9$ & $53.4 \pm 28.8$ \\
Total Suspended Solids $(\mathrm{mg} / \mathrm{L})$ & $19.6 \pm 7.6$ & $13.8 \pm 7.6$ & $15.2 \pm 7.8$ & $28.1 \pm 16.9$ & $13.8 \pm 10.3$ \\
pH & $6.8 \pm 0.2$ & $6.8 \pm 0.2$ & $6.6 \pm 0.2$ & $6.6 \pm 0.1$ & $6.6 \pm 0.1$ \\
Biological Oxygen Demand $(\mathrm{mg} / \mathrm{L})$ & $2.8 \pm 1.7$ & $2.6 \pm 1.5$ & $2.4 \pm 1.3$ & $2.4 \pm 1.7$ & $1.3 \pm 1.0$ \\
Chlorophyll-a $(\mu \mathrm{g} / \mathrm{L})$ & $127 \pm 77$ & $191 \pm 285$ & $136 \pm 132$ & $123 \pm 157$ & $66.7 \pm 82.3$ \\
Alkalinity $(\mathrm{mg} / \mathrm{L})$ & $55.4 \pm 3.3$ & $54.3 \pm 4.5$ & $55.5 \pm 4.1$ & $51.3 \pm 8.4$ & $44.2 \pm 6.1$ \\
Hardness $(\mathrm{mg} / \mathrm{L})$ & $22.7 \pm 3.0$ & $22.5 \pm 2.6$ & $22.3 \pm 3.0$ & $23.2 \pm 4.0$ & $18.2 \pm 2.3$ \\
\hline
\end{tabular}

$\mathrm{CC}=$ close to cages in the open-pond; $\mathrm{WO}=$ water outlet; IW12= water inlet receiving effluents from 12 fishponds; IW6= water inlet receiving effluents from 6 fishponds; IWM= water inlet opening into a macrophyte bed. 

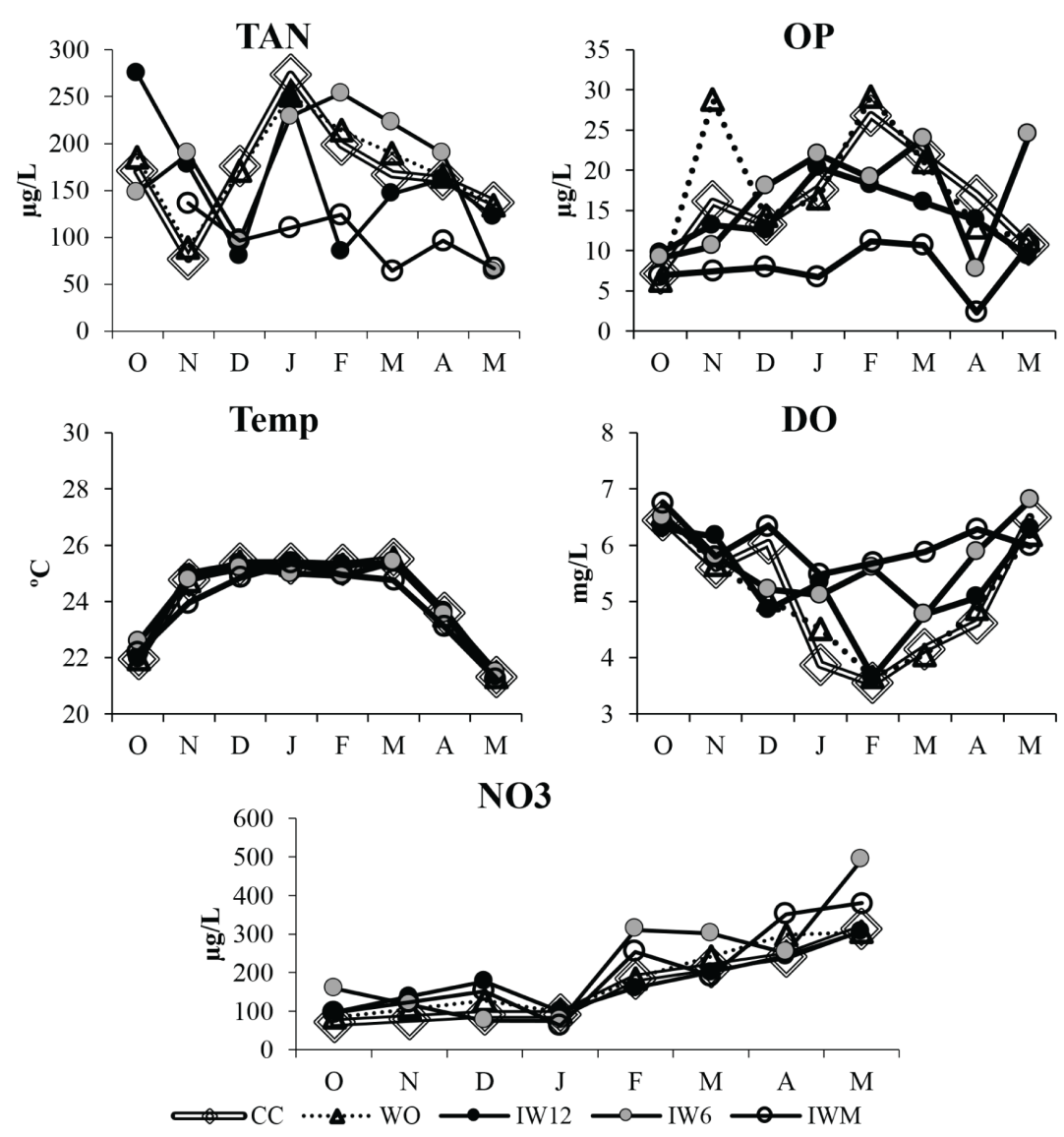

Figure 2. Monthly variation of total ammonia nitrogen (TAN), orthophosphate (OP), temperature (Temp), dissolved oxygen (DO) and nitrate (NO3) of the water samples sites (CC; WO; IW12; IW6; IWM) during the studied period.

Table 2. Principal Component coefficients.

\begin{tabular}{lcc}
\hline & PCA 1 & PCA 2 \\
\hline Temperature & -0.89 & -0.41 \\
Conductivity & -0.97 & 0.15 \\
Alkalinity & -0.97 & -0.05 \\
Hardness & -0.83 & -0.53 \\
pH & -0.70 & 0.28 \\
Dissolved Oxygen & 0.98 & -0.13 \\
Chlorophyll-a & -0.89 & -0.17 \\
Biological Oxygen Demand & -0.93 & -0.25 \\
Total Suspended Solids & 0.08 & -0.97 \\
Total Disolved Solids & -0.51 & 0.39 \\
Total Ammonia Nitrogen (TAN) & -0.85 & -0.40 \\
Nitrite & 0.75 & -0.65 \\
Nitrate & 0.64 & -0.77 \\
Orthophosphate & -0.97 & -0.16 \\
Total Phosphorus & -0.92 & 0.00 \\
Variance explained (\%) & 70 & 20 \\
\hline
\end{tabular}

with high positive PC1 value), and (b) decreased nitrification, as identified by the second principal component (IWM with positive PC2 value). Of the three water inlets, the least eutrophic was that in the macrophyte bed area. In fact, macrophytes absorb excessive loads of water nutrients and function as biological filters (Wal et al., 2013). The aquatic plants are highly capable of removing nutrients used for their growth and in the process they partially reduce loading, thus improving water quality. Many species of aquatic macrophytes and their dense beds have an enormous spatial heterogeneity and therefore play an important role in stabilizing environmental conditions (Albertoni et al., 2007). The macrophyte bed also acts as a trap for particles enhancing their sedimentation and having a clarifying effect on the water column and increases dissolved oxygen through photosynthesis (Verdegem et al., 2005).

Dissolved oxygen was high mainly from March on, when decreased in TAN and increased NO3 were observed. Ammonia concentrations are usually low in oxygenated waters of mesotrophic ponds due to its utilization by algae in the photic zone and nitrification to nitrogen oxidized forms (Ibrahim \& Naggar, 2010). The removal of nitrogen from the water is usually dominated by nitrate denitrification, concomitantly with the oxidation of organic matter (Liti et al., 2005). 


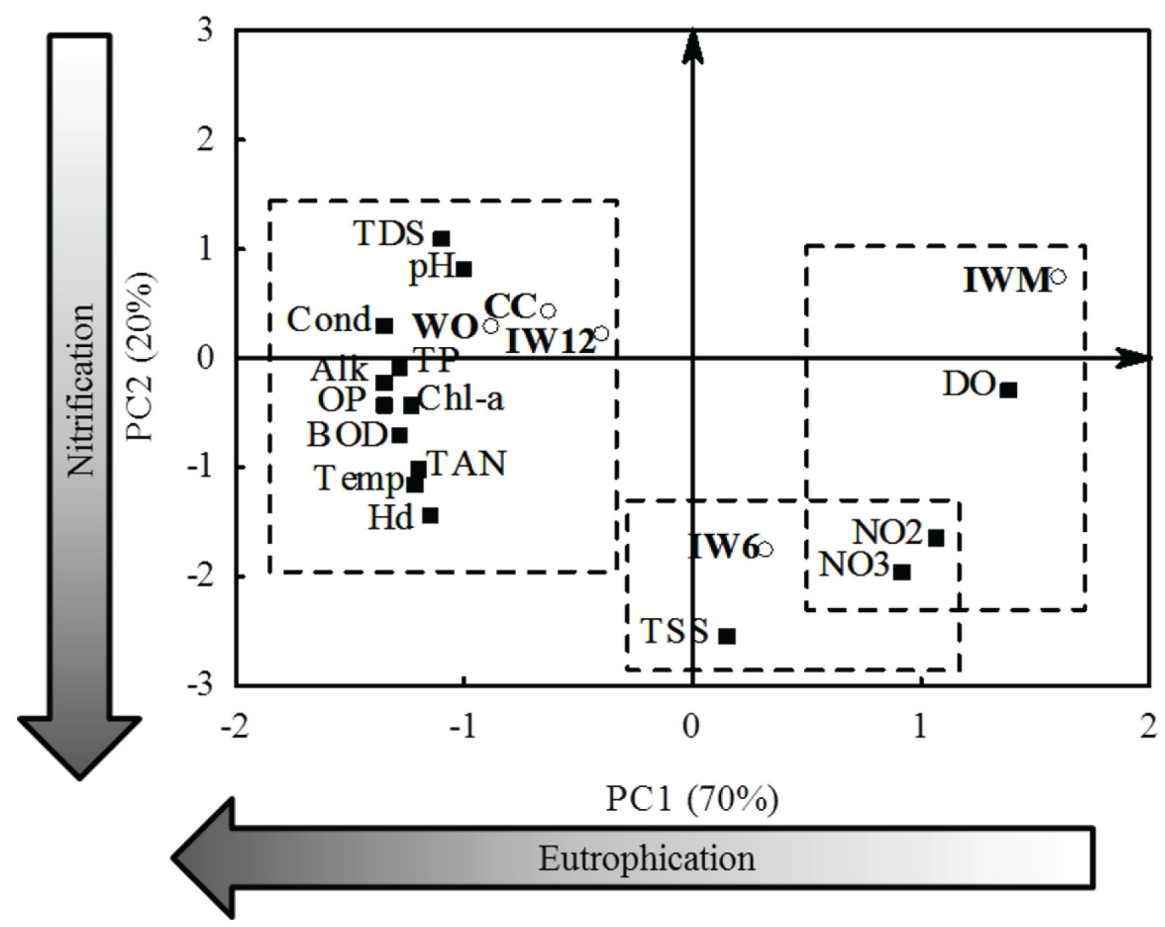

Figure 3. Interpolation of eigenvalues from the matrix of water variables. First two axis from the principal component analysis (PCA). Open circles = sites, filled squares = water variables. $\mathrm{CC}=$ close to cages in the open-pond, $\mathrm{WO}=$ water outlet, IW12= water inlet receiving effluents from 12 fishponds, IW6= water inlet receiving effluents from 6 fishponds, IWM= water inlet opening into a macrophyte bed, Alk= alkalinity, BOD= 5-day biochemical oxygen demand, $\mathrm{Chl}-\mathrm{a}=$ chlorophyll-a, Cond $=$ conductivity, $\mathrm{DO}=$ dissolved oxygen, $\mathrm{Hd}=$ hardness, $\mathrm{NO} 2=$ nitrite, $\mathrm{NO} 3=$ nitrate, $\mathrm{OP}=$ orthophosphate, $\mathrm{TAN}=$ total ammonia nitrogen, $\mathrm{TDS}=$ total dissolved solids, $\mathrm{Temp}=$ temperature, $\mathrm{TP}=$ total phosphorus, TSS= total suspended solids.

In the absence of a macrophyte bed and high feed inputs in IW6 site, sediments were not trapped, resulting in significantly higher TSS than in IWM, and in several months higher than in IW12. On the other hand, the suspended sediments supply substrate for attachment to nitrifying bacteria fostering nitrification, as identified by the second principal component (IW6 with high negative PC2 value). The dependence of nitrifying bacteria on substrate availability affects nitrite and nitrate concentrations in the water but not that of TAN because ammonia is more quickly absorbed by algae than by bacteria (Hargreaves, 1998), which explains the no participation of TAN in PC2.

Tilapia cages did not have much effect on water quality parameters, compared to the effects produced by inlet effluents. The high oxygen consumption by the growing fish during the warmest months (January-March) reduced dissolved oxygen in the cage area, which was partially compensated by aerators. Aeration for $10 \mathrm{~h}$ each night prevented DO from falling below $4 \mathrm{mg} \cdot \mathrm{L}^{-1}$. The higher total phosphorus and ions parameters values in the cage area than in the macrophyte bed inlet can be attributed to feed inputs and fish respiration and metabolites excretion in the cages. The similarity of the water quality in the cage and inlet sites indicate that water circulation through the flow-through system allowed the entering organic loading to be at least partially processed in the pond, so that the organic loading produced by the fish and their feeds in the cages did not increase the nutrients to a great extent, as would be expected in a stagnant system. Cages (CC) were located very close to the water outlet (WO), so that there was not enough space/time between both sites for the pond ecosystem to process the organic loading added in the cages, and similar water characteristics were recorded in both sites. Overall, water leaving the studied pond and entering the next pond in the flow-through series were just a little more eutrophic than water in the cage site and the most eutrophic inlet (PC1 of WO close and more negative than CC and IW12).

However, although tilapia survival was acceptable, its performance in the cages was poor as compared with results obtained in cages placed in standing and larger water bodies in which at 
higher densities during shorter culture period tilapia reached commercial size (Marengoni, 2006; Carvalho et al., 2010; Freato et al., 2012). This poor growth may indicate that the cages were too close to the pond bottom, and the water quality in the studied pond was not good enough for the tilapias, or that 80 tilapia $\mathrm{m}^{-2}$ was a too high density for the fish under the water quality conditions prevailing in this flow-through system, or most probably a combination of all these factors. The proximity of the cages to the pond bottom $(20 \mathrm{~cm})$ may have facilitated the entrance of substances that affect fish growth, mainly as fish activity produce strong water movements. At the beginning of this study frequent reduced oxygen levels near the cages occurred, forcing the continual use of nocturnal aeration after only 3 weeks of culture when fish biomass was still small. The aerators managed to keep appropriate oxygen levels thereafter, but may have not necessarily reduced negative effects of metabolites and organic loading on fish. The parasitosis outburst just after stocking was probably also promoted by the influence of sediment and poor water circulation and/or high fish density. A too high density for the given water quality conditions in the reduced water volume limited by the cages should have led to increased competition and social pressure, further reducing growth rate.

The integrated cage-pond technology may be utilized in flow-through systems if incoming water quality (mainly in the site W12) is improved. Cages would be positioned closer to the pond center where it is deeper allowing higher flow-through and dispersion of uneaten feed residues and feces from the cages. This would avoid their deposition beneath cages and reduce their negative influence on water quality entering the next fishpond (WO) and therefore not impair fish performance. Additional research is still required to generate knowledge of limnologic aspects of fish cage-pond relations in a flow-through system for the proper implementation of integrated and sustainable tilapia culture.

\section{Acknowledgements}

The authors would like to thank the Brazilian Council for Scientific and Technological Development (CNPq) for providing financial support and the colleagues of the Limnology and Plankton Production Laboratory for their instrumental assistance in field sampling and laboratory analysis. We would like to thank Dr. Dalton J. Carneiro for kindly providing the fish data.

\section{References}

ALBERTONI, E.F., PRELLVITZ, L.J. and PALMASILVA, C. Macroinvertebrate fauna associated with Pistia stratiotes and Nymphoides indica in subtropical lakes (south Brazil). Revista Brasileira de Biologia, 2007, 67(3), 499-507. http://dx.doi.org/10.1590/ S1519-69842007000300015. PMid:18094833.

BOYD, C.E. and TUCKER, C.S. Water quality and pond soil analyses for aquaculture. Auburn: Alabama Agricultural Experiment Station, 1992, 183 p.

CARVAlHO, E.D., CAMARGO, A.L.S. and ZANATTA, A.S. Productive development of Nile tilapia raised in net cages at a public reservoir: brief analysis of the empirical model of classification. Ciência Rural, 2010, 40(7), 1616-1622. http:// dx.doi.org/10.1590/S0103-84782010000700021.

DEGEFU, F., MENGISTU, S. and SCHAGERL, M. Influence of fish cage farming on water quality and plankton in fish ponds: a case study in the Rift Valley and North Shoa reservoirs, Ethiopia. Aquaculture, 2011, 316(1-4), 129-135. http://dx.doi. org/10.1016/j.aquaculture.2011.03.010.

FREATO, T.A., FREITAS, R.T.F., PIMENTA, M.E.S.G., OLIVEIRA, G.R., REIS NETO, R.V. and MATTOS, B.O. Evaluation of Nile tilapia strains cultivated in cages under different feeding programmes. Revista Brasileira de Zootecnia, 2012, 41(6), 1332-1336. http://dx.doi.org/10.1590/ S1516-35982012000600002.

GOLTERMAN, H.L., CLYMO, R.S. and OHNSTAD, M.A.M. Methods for physical and chemical analysis of fresh water. Oxford: Blackwell Scientific Publication, 1978, 214 p.

HARGREAVES, J.A. Nitrogen biogeochemistry of aquaculture ponds. Aquaculture, 1998, 166(3), 181-212. http://dx.doi.org/10.1016/S00448486(98)00298-1.

HUO, Y., WU, H., CHAI, Z., XU, S., HAN, F., DONG, L. and HE, P. Bioremediation efficiency of Gracilaria verrucosa for an integrated multi-trophic aquaculture system with Pseudosciaena crocea in Xiangshan harbor, China. Aquaculture (Amsterdam, Netherlands), 2012, 326-329(25), 99-105. http:// dx.doi.org/10.1016/j.aquaculture.2011.11.002.

IBRAHIM, N. and NAGGAR, G.E. Water quality, fish production and economics of Nile tilapia, Oreochromis niloticus, and african catfish, Clarias gariepinus, monoculture and polycultures. Journal of the World Aquaculture Society, 2010, 41(4), 574-582. http:// dx.doi.org/10.1111/j.1749-7345.2010.00397.x.

KOROLEFF, F. Determination of nutrients. In E. GRASHOF and E. KREMLING, eds. Methods of seawater analysis. German: Verlag Chemie Wenhein, 1976, $181 \mathrm{p}$.

LEGENDRE, P. and LEGENDRE, L. Numerical ecology. Amsterdan: Elsevier Science B.V., 1998, 852 p. 
LITI, D.M., FULANDA, B., MUNGUTI, J.M., STRAIF, M., WAIDBACHER, H. and WINKLER, G. Effects of open-pond density and caged biomass of Nile tilapia (Oreochromis niloticus L.) on growth, feed utilization, economic returns and water quality in fertilized ponds. Aquaculture Research, 2005, 36(15), 1535-1543. http://dx.doi.org/10.1111/j.13652109.2005.01376.x.

MACKERETH, F.J.H., HERON, J. and TALLING, F.J. Water analysis: some revised methods for limnologists. England: Titus Wilson and So., 1978, 121 p.

MARENGONI, N.G. Production of Nile tilapia Oreochromis niloticus (Chitralada strain) reared in cages with different stocking densities. Archivos de Zootecnia, 2006, 55(210), 127-138.

NUSCH, E.A. Comparison of different methods for chlorophyll and phaeopigments determination. Archiv für Hydrobiologie, 1980, 14, 14-36.

STATSOFT INC. Statistica: data analysis software system. Version 8 [online]. Tulsa, 2007 [viewed 30 Apr. 2014]. Available from: www.statsoft.com

VERDEGEM, M.C.J., EDING, E.H., SERETI, V., MUNUBI, R.N., SANTACRUZ REYES, R.A. and VAN DAM, A.A. Similarities between microbial and periphytic biofilms in aquaculture systems. In M.E. AZIM, M.C.J. VERDEGEM, A.A. VAN Dam and M.C.M. BEVERIDG, eds. Periphyton: ecology, exploitation and management. Netherlands: CABI Publishing, 2005, 319 p.

VISTA, A., NORRIS, P., LUPI, F. and BERNSTEN, R. Nutrient loading and efficiency of tilapia cage culture in Taal lake, Philippines. The Philippine Agriculture Scientist, 2006, 89(1), 48-57.
WAIDBACHER, H., LITI, D.M., FUNGOMELI, M., MBALUKA, R.K., MUNGUTI, J.M. and STRAIF, M. Influence of pond fertilization and feeding rate on growth performance, economic returns and water quality in a small-scale cage-cumpond integrated system for production of Nile tilapia (Oreochromis niloticus L.). Aquaculture Research, 2006, 37(6), 594-600. http://dx.doi.org/10.1111/ j.1365-2109.2006.01467.x.

WAL, J.E.M., DORENBOSCH, M., IMMERS, A.K., FORTEZA, C.V., GEURTS, J.J.M., PEETERS, E.T.H.M., KOESE, B. and BAKKER, E.S. Invasive crayfish threaten the development of submerged macrophytes in lake restoration. PLoS One, 2013, 8(10), 1-11. PMid:24205271.

YADAV, R.K., SRESTHA, M.K. and PANDIT, N.P. Introduction of Sahar (Tor putitora) in cage-cumpond integration system of mixed-sex Nile tilapia (Oreochromis niloticus). Our Nature, 2007, 5(1), $52-$ 59. http://dx.doi.org/10.3126/on.v5i1.798.

YI, Y. and LIN, C.K. Cage-cum-pond: integrated aquaculture systems recycle wastes. Advocate, 2001a, 4(6), 65-66.

YI, Y. and LIN, C.K. Effects of biomass of cage Nile tilapia (Oreochromis niloticus) and aeration on the growth and yields in an integrated cage-cum-pond system. Aquaculture, 2001b, 195(3-5), 253-267. http://dx.doi.org/10.1016/S0044-8486(00)00558-5.

Received: 30 April 2014 Accepted: 03 May 2016 